\title{
The influence of regional circulation patterns on wet and dry mineral dust and sea salt deposition over Greenland
}

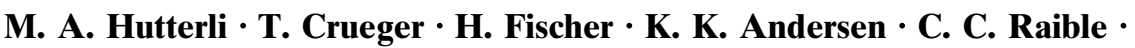 \\ T. F. Stocker · M. L. Siggaard-Andersen · J. R. McConnell · R. C. Bales · \\ J. F. Burkhart
}

Received: 30 June 2006/ Accepted: 16 October 2006/ Published online: 29 November 2006

(C) Springer-Verlag 2006

\begin{abstract}
Annually resolved ice core records from different regions over the Greenland ice sheet (GrIS) are used to investigate the spatial and temporal variability of calcium $\left(\mathrm{Ca}^{2+}\right.$, mainly from mineral dust $)$ and sodium $\left(\mathrm{Na}^{+}\right.$, mainly from sea salt) deposition. Cores of high common inter-annual variability are grouped with an EOF analysis, resulting in regionally representative $\mathrm{Ca}^{2+}$ and $\mathrm{Na}^{+}$records for northeastern and central Greenland. Utilizing a regression and validation method with ERA-40 reanalysis data, these
\end{abstract}

M. A. Hutterli · C. C. Raible · T. F. Stocker

Physics Institute, University of Bern,

Sidlerstrasse 5, 3012 Bern, Switzerland

M. A. Hutterli $(\square)$

Physical Sciences Division, British Antarctic Survey,

High Cross, Madingley Road, Cambridge CB3 0ET, UK

e-mail: mahut@bas.ac.uk

T. Crueger

Max-Planck-Institute for Meteorology, Hamburg,

Bundesstrasse 53, 20146 Hamburg, Germany

H. Fischer

Alfred-Wegener-Institute for Polar and Marine Research, Bremerhaven, Columbusstrasse, 27568 Bremerhaven,

Germany

K. K. Andersen · M. L. Siggaard-Andersen

Niels Bohr Institute, University of Copenhagen,

Juliane Maries Vej 30, 2100 Copenhagen, Denmark

J. R. McConnell

Desert Research Institute, 2215 Raggio Parkway,

Reno, NV 89512, USA

R. C. Bales · J. F. Burkhart

University of California, Merced, 4225 N. Hospital Road,

Atwater, CA 95301, USA common records are associated with distinct regional atmospheric circulation patterns over the North American Arctic, Greenland, and Central to Northern Europe. These patterns are interpreted in terms of transport and deposition of the impurities. In the northeastern part of the GrIS sea salt records reflect the intrusion of marine air masses from southeasterly flow. A large fraction of the $\mathrm{Ca}^{2+}$ variability in this region is connected to a circulation pattern suggesting transport from the west and dry deposition. This pattern is consistent with the current understanding of a predominantly Asian source of the dust deposited over the GrIS. However, our results also indicate that a significant fraction of the inter-annual dust variability in NE and Central Greenland is determined by the frequency and intensity of wet deposition during the season of high atmospheric dust loading, rather than representing the variability of the Asian dust source and/or long-range transport to Greenland. The variances in the regional proxy records explained by the streamfunction patterns are high enough to permit reconstructions of the corresponding regional deposition regimes and the associated circulation patterns.

\section{Introduction}

The atmospheric dynamics in specific regions of the globe are dominated by pronounced atmospheric modes such as the Antarctic Oscillation (AAO), the El Niño Southern Oscillation (ENSO), and the North Atlantic Oscillation (NAO) or Arctic Oscillation (AO) (Gong and Wang 1999; Thompson and Wallace 2000; 
Wallace and Thompsonu 2002; Philander 1990; Hurrell et al. 2001; Barnston and Livezey 1987). The advent of the NCEP/NCAR (Kalnay et al. 1996) and the ERA40 (Simmons and Gibson 2000) reanalysis products has greatly facilitated research on such teleconnection patterns between local variables and large-scale atmospheric behavior. Due to the spatial and temporal limitation of reliable instrumental input data, however, these reanalysis data sets only cover the last $\sim 50$ years.

In order to investigate climate variability over longer time periods, great effort has been put into the reconstruction of time series of the strength of specific circulation patterns beyond the instrumental record using natural climate archives and documentary evidence (Appenzeller et al. 1998; Luterbacher et al. 2002; Cook et al. 2002; Casty et al. 2006; Raible et al. 2006; Vinther et al. 2003).

Appenzeller et al. (1998) for example use snow accumulation records from a western Greenland ice core to reconstruct the NAO. In this region snowfall is strongly influenced by the blocking of cyclones over the North Atlantic during negative NAO phases, i.e. when a reduced pressure gradient between Iceland and the Azores prevails. While the NAO is clearly reflected in this specific ice core accumulation record, it does not dominate the inter-annual accumulation variability in other parts of the Greenland ice sheet (GrIS) and does not necessarily control the variability observed in other ice core proxies (Hutterli et al. 2005; Mosley-Thompson et al. 2005; Crüger et al. 2004). Thus, rather than identifying a specific circulation pattern in ice core records, Hutterli et al. (2005) reversed the question and determined the synoptic atmospheric circulation patterns that are responsible for the snow accumulation variability in various regions of the GrIS based purely on ERA-40 data. A similar approach was taken by Fischer and Mieding (2005) for sea salt aerosol records from northeastern Greenland ice cores.

Here we largely extend these studies by investigating ice core $\mathrm{Na}^{+}$and $\mathrm{Ca}^{2+}$ records from various regions of the GrIS. These aerosol species are proxies for the transport and deposition of sea salt aerosol and mineral dust, respectively, onto the Greenland ice sheet. Air masses of marine origin transport moisture and sea salt aerosols to the GrIS. They are linked to cyclonic activity over the nearby seas and snow deposition over the ice sheet (Fischer and Mieding 2005; Hutterli et al. 2005). In contrast to snow accumulation records, however, aerosol species are not necessarily linked to air masses that are connected to snowfall over the ice sheet. Due to the additional dry deposition of particles, aerosol variables in ice core records can also document the influence of circulation patterns independent from precipitation events.

Another aspect of these aerosol records is that they show a clear seasonal cycle with a maximum in winter/ spring and spring for sea salt and mineral dust, respectively (e.g. Legrand and Mayewski 1997; Whitlow et al. 1992; Steffensen 1988). Variations in the amplitude of this pronounced seasonal maximum also dominate the inter-annual variability in the chemistry records, while the baseline values for off-season are very low and do not contribute significantly to the inter-annual variability (e.g. Legrand and Mayewski 1997). Thus, variability in the records of both aerosol species are expected to represent the circulation patterns encountered during winter and spring, i.e. when the variability in atmospheric circulation is largest in the North Atlantic region.

The objectives of our study are to gain a mechanistic understanding of the influence of atmospheric dynamics on aerosol transport and deposition onto the GrIS, to identify those circulation patterns that are responsible for inter-annual variability in these ice core records, and to calibrate the latter for future climate reconstructions. For this we derived regression models, which link circulation patterns to regional ice core time series that in turn represent considerable amounts of common variability in a few ice cores.

\section{Data and methods}

\subsection{Data}

Two different types of data are used for this study: ice core data from different drill sites on the GrIS and reanalysis data.

The ice core data comprise $12 \mathrm{Ca}^{2+}$ and $5 \mathrm{Na}^{+}$records from the GrIS (Fig. 1 and Table 1). The selection criteria for choosing records are data quality (annually resolved and stratigraphically dated with an estimated error $<1$ year), time period covered (at least 1960-1993 to have an adequate overlap with the ERA-40 reanalysis data), and data availability. The analytical accuracy is typically better than $10 \%$ of an individual measurement. Details on sampling and analysis can be found in the original publications as indicated in Table 1 . The high-resolution data was dated by assigning the $\mathrm{Na}^{+}$or $\mathrm{Ca}^{2+}$ peaks to spring (i.e. fractional year $n+0.25)$ and assuming a linear depth-age relationship between neighboring years. The annual mean of year $n$ was then calculated by averaging from fall of year $n-1$ (i.e. $n-1+0.75)$ to fall of year $n$ (i.e. $n+0.75$ ) in order 


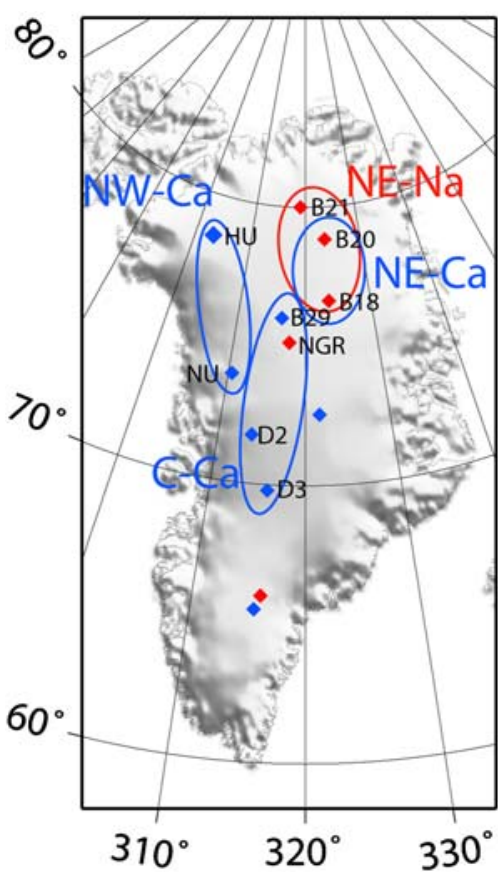

Fig. 1 Map of the Greenland ice core records. In red are cores where both, $\mathrm{Ca}^{2+}$ and $\mathrm{Na}^{+}$records were available, blue only $\mathrm{Ca}^{2+}$. Named cores were selected for the four regional groups resulting from the EOF analysis (see Sect. 2). The four groups, which were subsequently used for the regression/validation model, are also depicted

to ensure that the $\mathrm{Ca}^{2+}$ and $\mathrm{Na}^{+}$peak of the winter/ spring season of year $n$ only contributes to the mean of year $n$.

The second data set used is the ERA-40 reanalysis recently provided by the European Centre for Medium Range Forecasts (ECMWF). ECMWF uses its operational forecasting model system with a horizontal resolution of $\mathrm{T} 159\left(1.125 \times 1.125^{\circ}\right)$ and 60 vertical levels to generate the ERA-40 reanalysis data (Simmons and Gibson 2000). We use the monthly means of the streamfunction at $500 \mathrm{hPa}$. The streamfunction pattern closely resembles the geopotential height. The latter, however, also includes a small contribution from thermodynamical effects, whereas the streamfunction is a purely dynamical entity, which was the reason we chose it. The streamfunction can be obtained from:

$\nabla^{2} \psi=\frac{\partial v}{\partial x}-\frac{\partial u}{\partial y}$.

Here $\nabla^{2}$ denotes the Laplacian operator, $\Psi$ the streamfunction, and $v$ and $u$ the horizontal wind components. Since we were interested in large-scale circulation patterns and for reasons of numerical efficiency we calculated the streamfunction from the horizontal wind components on a T21 grid with grid
Table 1 Locations and specifications of ice core records used (X's annotate available records, and in upper-case the records defining the four groups in Table 2)

\begin{tabular}{|c|c|c|c|c|}
\hline Site & Location & $\begin{array}{l}\text { Method, } \\
\text { sample } \\
\text { resolution }\end{array}$ & $\mathrm{Ca}^{2+}$ & $\mathrm{Na}^{+}$ \\
\hline $\mathrm{B} 18^{\mathrm{a}}$ & $76.62^{\circ} \mathrm{N} 36.40^{\circ} \mathrm{W}$ & $\mathrm{IC}, 3-5 \mathrm{~cm}$ & $\mathrm{X}$ & $\mathrm{X}$ \\
\hline $\mathrm{B} 20^{\mathrm{a}}$ & $78.83^{\circ} \mathrm{N} 36.50^{\circ} \mathrm{W}$ & $\mathrm{IC}, 3-5 \mathrm{~cm}$ & $\mathrm{X}$ & $\mathrm{X}$ \\
\hline $\mathrm{B} 21^{\mathrm{a}}$ & $80.00^{\circ} \mathrm{N} 41.13^{\circ} \mathrm{W}$ & IC, $3-5 \mathrm{~cm}$ & $\mathrm{x}$ & $\mathrm{X}$ \\
\hline $\mathrm{B} 29^{\mathrm{b}}$ & $76.00^{\circ} \mathrm{N} 43.50^{\circ} \mathrm{W}$ & $\mathrm{CFA}, 1 \mathrm{~cm}$ & $\mathrm{X}$ & \\
\hline $\mathrm{D} 2^{\mathrm{c}}$ & $71.75^{\circ} \mathrm{N} 46.16^{\circ} \mathrm{W}$ & $\mathrm{CFA}, 1 \mathrm{~cm}$ & $\mathrm{X}$ & \\
\hline $\mathrm{D} 3^{\mathrm{c}}$ & $69.80^{\circ} \mathrm{N} 44.00^{\circ} \mathrm{W}$ & $\mathrm{CFA}, 1 \mathrm{~cm}$ & $\mathrm{X}$ & \\
\hline Das1 ${ }^{\mathrm{d}}$ & $66.00^{\circ} \mathrm{N} 43.99^{\circ} \mathrm{W}$ & $\mathrm{CFA}, 1 \mathrm{~cm}$ & $\mathrm{x}$ & $\mathrm{x}$ \\
\hline Humboldt (HU) ${ }^{\mathrm{e}}$ & $78.53^{\circ} \mathrm{N} 56.83^{\circ} \mathrm{W}$ & $\mathrm{CFA}, 1 \mathrm{~cm}$ & $\mathrm{X}$ & \\
\hline NASA-U (NU) & $73.84^{\circ} \mathrm{N} 49.50^{\circ} \mathrm{W}$ & $\mathrm{CFA}, 1 \mathrm{~cm}$ & $\mathrm{X}$ & \\
\hline NGRIP $(\mathrm{NGR})^{\mathrm{f}}$ & $75.10^{\circ} \mathrm{N} 42.32^{\circ} \mathrm{W}$ & $\mathrm{IC}, 5 \mathrm{~cm}$ & $\mathrm{X}$ & $\mathrm{x}$ \\
\hline Summit99g & $72.55^{\circ} \mathrm{N} 38.31^{\circ} \mathrm{W}$ & CFA, $1 \mathrm{~cm}$ & $\mathrm{x}$ & \\
\hline $\mathrm{UAK} 1^{\mathrm{c}}$ & $65.50^{\circ} \mathrm{N} 43.99^{\circ} \mathrm{W}$ & $\mathrm{CFA}, 1 \mathrm{~cm}$ & $\mathrm{x}$ & \\
\hline
\end{tabular}

The sample resolution and measurement technique only applies for the data used in this study

IC Ion chromatography, CFA Continuous Flow Analysis (Röthlisberger et al. 2000)

a Fischer and Mieding 2005; Mieding 2005; Fischer 1997

b Sommer 1996

c Burkhart et al. 2006

d McConnell et al. 2002a

e Anklin et al. 1998

f NorthGRIP Members 2004; Vinther et al. 2006; Andersen unpublished data 2006

g McConnell et al. 2002b

distances of about $5.6^{\circ}$ in zonal and meridional direction by interpolating the original data accordingly.

\subsection{Grouping of ice core data}

To group the ice cores geographically the $\mathrm{Ca}^{2+}$ and $\mathrm{Na}^{+}$ series were first detrended. The logarithm of these detrended time series are used to account for the lognormal distribution of concentration data and normalized such that the time series have zero mean and unit variance. Thus it is guaranteed that all time series have initially the same variance. We then derived the first empirical orthogonal function (EOF) of various starting groups of $\mathrm{Ca}^{2+}$ and $\mathrm{Na}^{+}$series, respectively, for the longest common time period. These starting groups (including the group containing all available $\mathrm{Ca}^{2+}$ or $\mathrm{Na}^{+}$series) were somewhat subjectively chosen as first guesses representing large coherent areas of the GrIS. From each starting group we identified potential subgroups of spatially coherent records with consistently positive (or negative) loadings of EOF1 and thus common variability. The EOF procedure was then repeatedly performed on each subgroup while removing individual cores with small loadings. This way a 
number of final groups was identified, each containing a set of ice core records that all have considerable loadings, i.e. common variability. The principal component PC1 of each group for the period 1960-1993 is then the time series representing the largest amount of common inter-annual variability of the ice cores. It is assumed that these PC1s represent a common climate signal of the specific region of the GrIS, because the potential glaciological and analytical noise of the original records is removed by this technique.

Applying the EOF procedure, three groups of ice cores with common $\mathrm{Ca}^{2+}$ and one group with common $\mathrm{Na}^{+}$variability are identified from the originally 12 $\mathrm{Ca}^{2+}$ and $5 \mathrm{Na}^{+}$records (Fig. 1). Details of the $8 \mathrm{Ca}^{2+}$ and $3 \mathrm{Na}^{+}$ice core records used in the four groups are given in Table 1 and the records are shown in Fig. 2. In Table 2 the four groups, the ice cores they contain, and the name used hereafter for the corresponding regional time series (i.e. the PC of the first EOF) are listed. The fact that the Summit99 record is not part of a group is in line with earlier results for accumulation records indicating that records from an area of similar meteorological influence away from ice divides and domes are likely to show the strongest common variability and are thus best used to reconstruct circulation patterns (Hutterli et al. 2005).

\subsection{Regression technique}

The regression technique used here identifies the atmospheric circulation pattern and its seasonal and spatial extent, for which the inter-annual variability has the strongest correlation with a given proxy time series. The monthly means of the streamfunction at the $500 \mathrm{hPa}$ level, which describe the upper troposphere circulation, and the four regional aggregated ice core time series (NE-Ca, NE-Na, C-Ca, NW-Ca, Table 2) have been used for the statistical regression. Our method is based on the calibration of the regional $\mathrm{Ca}^{2+}$ and $\mathrm{Na}^{+}$time series against one or more selected principal components (PCs) of the streamfunction EOFs. The regression technique repeatedly applies an EOF analysis and searches for the streamfunction PCs that have the highest correlation with $\mathrm{PC} 1$ of one ice core group while systematically varying both, the spatial boundaries of the streamfunction field and the length and timing (i.e. the season) over which it is averaged. Thus, this regression algorithm identifies both the spatial extent and the season for which the streamfunction pattern is most strongly related to the inter-annual variability of one ice core group. The procedure is repeated for each of the ice core groups resulting in the objective identification of the distinct
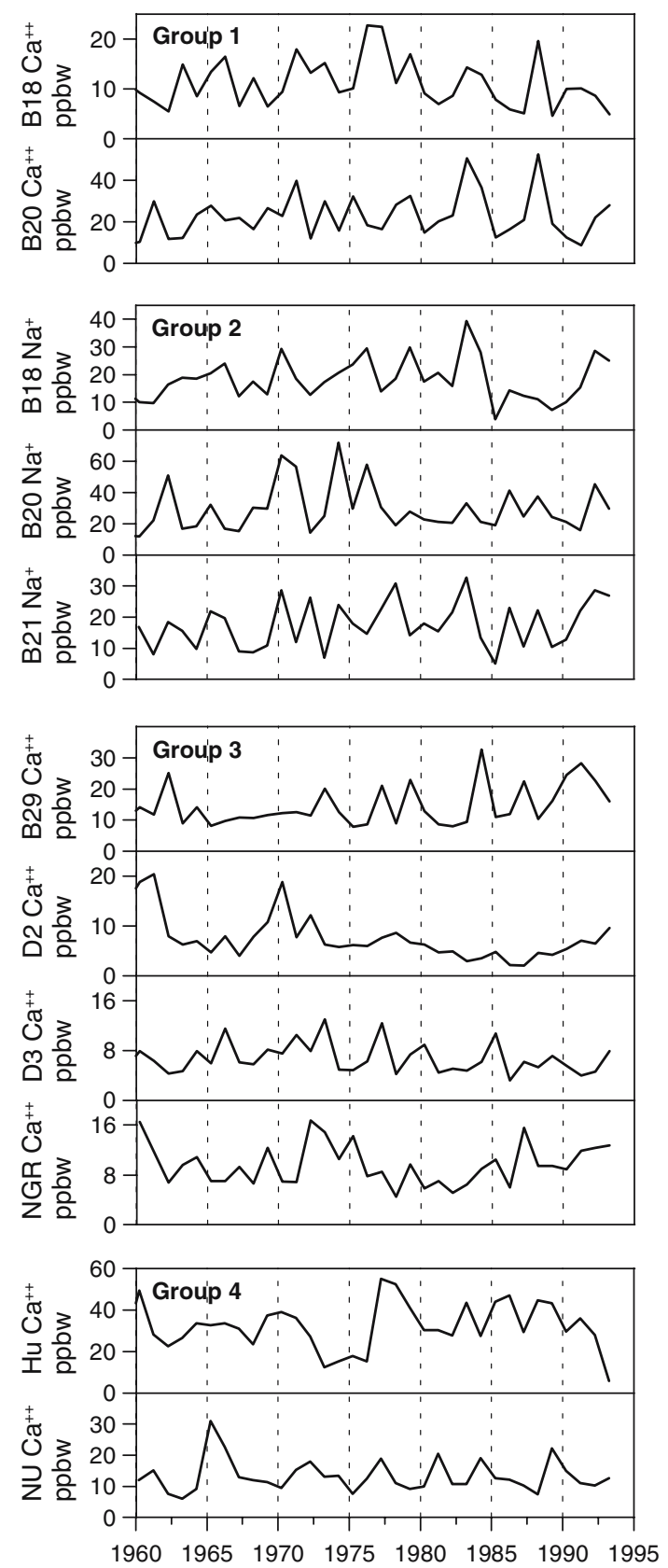

Fig. 2 The $\mathrm{Ca}^{2+}$ and $\mathrm{Na}^{+}$records used in the regressionvalidation model resulting in the groups 1-4 (see also Table 2 and Fig. 1)

streamfunction patterns presented in Sect. 3. Only those streamfunction PCs that considerably contribute to the estimation ( $>25 \%$ explained variance, if only one PC is used, $>10 \%$ explained variance, for additional PCs) have been used for calibration.

After the PCs with the highest correlation values were found, the relationship is validated. Validation is a necessary procedure to prove the calibration. For that reason we reconstruct the proxy time series (here 
Table 2 Four groups of ice core records with common variability identified with the EOF analysis and the names used hereafter for the corresponding time series, which are the first principal components, $\mathrm{PC} 1$, of each group

\begin{tabular}{llll}
\hline Group & Species & Cores (loadings for PC1) & $\begin{array}{l}\text { Name of } \\
\text { PC1 }\end{array}$ \\
\hline 1 & $\mathrm{Ca}^{2+}$ & B18 (0.79), B20 (0.79) & NE-Ca \\
2 & $\mathrm{Na}^{+}$ & B18 (0.87), B20 (0.66), B21 (0.80) & NE-Na \\
3 & $\mathrm{Ca}^{2+}$ & B29 (0.53), D2 (0.60), D3 (0.74), & C-Ca \\
& & NGR (0.66) & NW-Ca \\
4 & $\mathrm{Ca}^{2+}$ & Hu (0.73), NU (0.73) \\
\hline
\end{tabular}

In brackets the loading of each ice core record to $\mathrm{PC} 1$ is shown. The loading represents the correlation between the single ice core time series and PC1 and its square is the variance of the ice core time series explained by the PC. The mean of these variances is the explained variance of the EOF. Thus, the loadings are a measure of the contribution of the single cores to the EOF variability

PC1 of the ice core group) using the streamfunction PCs with data of a period that has not been used for calibration. If time series have a sufficient length,
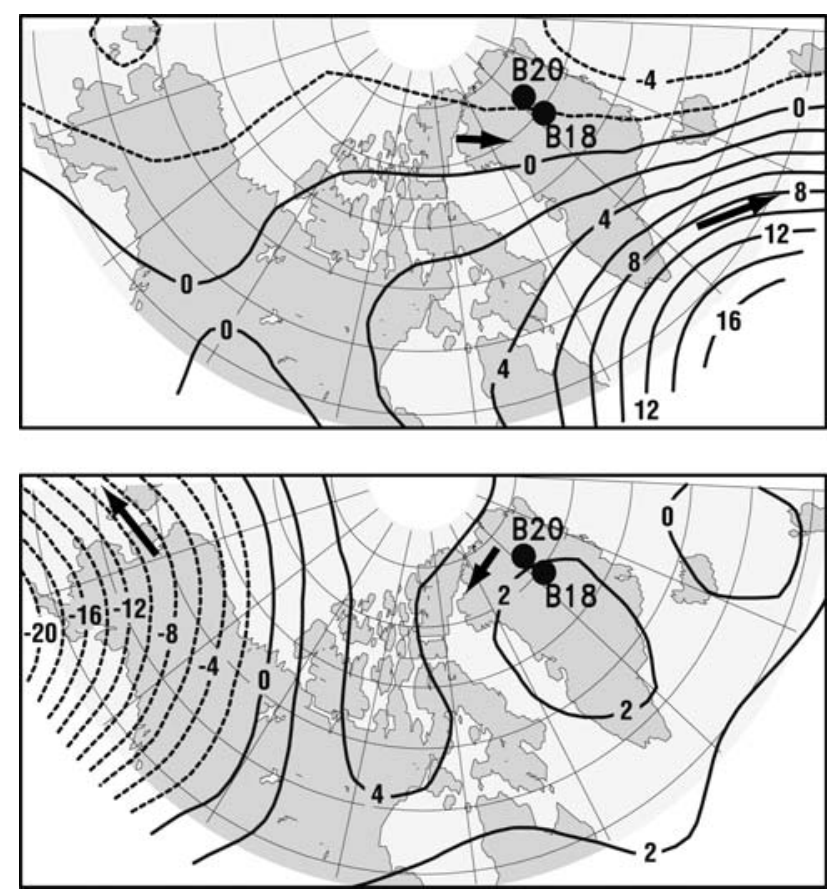

Fig. 3 EOF-patterns linked to NE-Ca for the case of positive $\mathrm{Ca}^{2+}$ concentration anomalies: streamfunction in units of $10^{5} \mathrm{~m}^{2} / \mathrm{s}^{2}$ averaged from March to August. a Second EOF, EOF2 $\Psi(\mathrm{NE}-\mathrm{Ca})$, representing $13 \%$ of the streamfunctions' variability, explaining $30 \%$ of the record. b First EOF, EOF1 ${ }_{\Psi}(\mathrm{NE}-\mathrm{Ca})$, representing $26 \%$ of the streamfunctions' variability and describing $14 \%$ of the NE-Ca record. Shown is the full spatial extent of the pattern as determined by the regression model. Arrows indicate the local wind direction and wind speed anomaly (proportional to the length of the arrow) and are displayed to facilitate the interpretation of the pattern validation can easily be done by dividing the time series into two parts. One part is used for calibration, the other for reconstruction and vice versa. Since the time series used here are too short for this method, we applied the cross-validation technique, a method specifically developed for short time series (Michaelsen 1987). In this method, one time step-the validation time step-is removed from the entire series and a calibration between ice core and streamfunction is performed with the reduced time series. Afterwards this relationship is used to estimate the value of the ice core record for the validation time step. This method is performed in a stepwise way, finally leading to an entirely validated regional ice core time series explaining a portion of the variance of the 'real' ice core time series. By varying the temporal and spatial extent of the streamfunction, we searched for a reconstruction with the highest amount of explained variance. In this study, we only accepted regression models describing about $30 \%$ of the ice core records' variance after validation. The calibration and validation procedure used has been applied earlier and is described in more detail by Crüger and von Storch (2002) and Crüger et al. (2004). They searched for circulation (streamfunction) as well as for thermodynamic (temperature) patterns related to ice core accumulation. However, thermodynamics proved to have no significant effect on snow deposition and is expected to be even less important for aerosol deposition. Accordingly, in this study the procedure has been simplified in such a way that we only looked for circulation patterns that are linked to the ice core records.

\section{Results}

The regression analysis and validation led to streamfunction patterns representing spring-summer (NE$\mathrm{Ca}$ ), winter-spring (NE-Na, C-Ca) and winter-summer (NW-Ca). This finding is approximately in line with the current understanding of the seasons with the highest variability (for $\mathrm{Ca}^{2+}$ mainly the spring, for $\mathrm{Na}^{+}$the winter season).

For NE-Ca (defined by 2 ice cores), two streamfunction patterns were identified, representing the time from March to August and covering the area from Alaska, northern Canada to Svalbard (Fig. 3). Although the timing of the seasonal correlation identified by our automatic regression analysis extends into the summer months with low $\mathrm{Ca}^{2+}$ concentrations, the months of the highest $\mathrm{Ca}^{2+}$ variability (generally March-May) are included, providing independent support of the validity of our regression method. The 
second EOF of the streamfunction $\Psi[\mathrm{EOF} 2 \Psi(\mathrm{NE}-$ $\mathrm{Ca})$, representing $13 \%$ of the streamfunctions' variability, explains $30 \%$ of the variability in the NE-Ca record (Fig. 3a). The streamfunction patterns can be interpreted as follows: The flow is tangent to the streamfunction contours with increasing streamfunction values on the right hand side of the flow. Increased wind speed is indicated by more closely spaced contour lines. To facilitate the interpretation of the streamfunction patterns some arrows indicating the direction and the speed of the local wind are displayed in the figures. The pattern of $\mathrm{EOF} 2_{\Psi}(\mathrm{NE}-\mathrm{Ca})$ represents a westerly flow over the northern parts of Greenland. The first EOF $\left[\mathrm{EOF} 1_{\Psi}(\mathrm{NE}-\mathrm{Ca})\right.$, Fig. 3b] represents $26 \%$ of the streamfunction variability and describes $14 \%$ of the variability in the NE-Ca record. This pattern is characterized by a weak cyclonic flow over Greenland, indicating transport from the south-east/ east to the drill sites.

Similar to NE-Ca, also for the NE-Na record (defined by three ice cores) one EOF has been identified indicating marine air masses from the Greenland sea being advected to the region (Fig. 4) but with much stronger flow regime around the drill sites for the February-March period. This fifth EOF [EOF5 ${ }_{\Psi}(\mathrm{NE}-$ $\mathrm{Na})$ ] describes $30 \%$ of the variability in the NE-Na record $(9 \%$ explained variance of the streamfunction field). The timing of February-March is earlier than that of NE-Ca (March-August), which is consistent with the seasonality in the ice core data.

In the central Greenland region, the $\mathrm{C}$-Ca record (defined by four ice cores) is related to the pattern EOF2 $\Psi(\mathrm{C}-\mathrm{Ca})$ explaining $22 \%$ of the variance of the

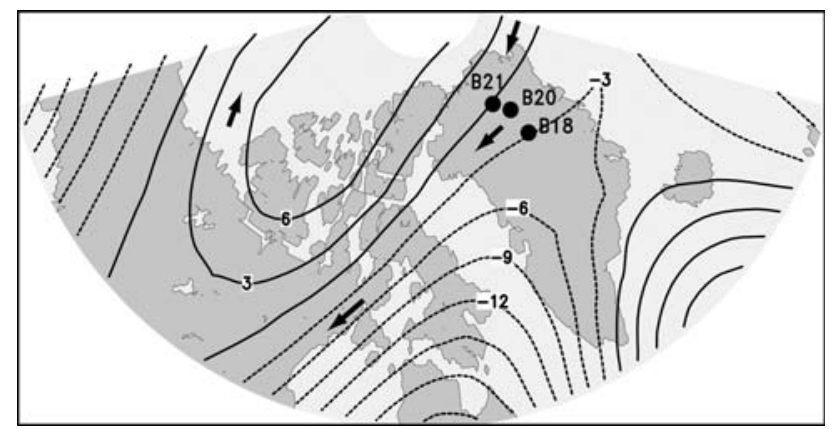

Fig. 4 EOF-pattern linked to NE-Na for the case of positive $\mathrm{Na}^{+}$ concentration anomalies: Streamfunction in units of $10^{5} \mathrm{~m}^{2} / \mathrm{s}^{2}$ averaged over February/March: 5th EOF, EOF5 $\Psi(\mathrm{NE}-\mathrm{Na})$, representing $9 \%$ of the streamfunctions' variability, explaining $30 \%$ of the record. Shown is the full spatial extent of the pattern as determined by the regression model. Arrows indicate the local wind direction and wind speed anomaly (proportional to the length of the arrow) and are displayed to facilitate the interpretation of the pattern

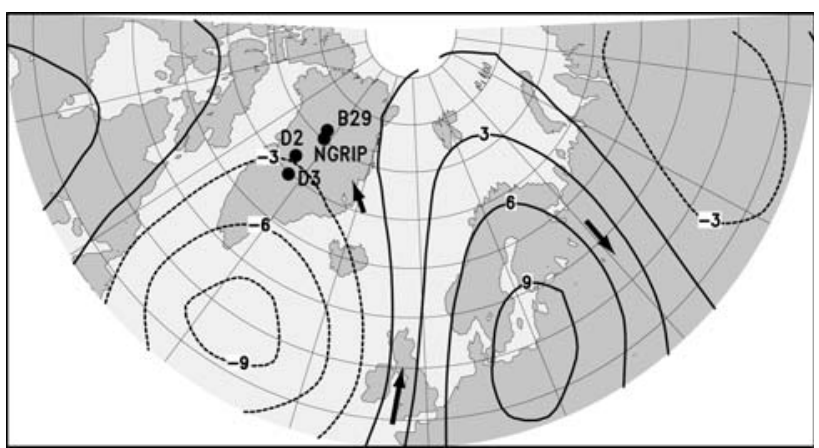

Fig. 5 EOF-pattern linked to C-Ca for the case of positive $\mathrm{Ca}^{2+}$ concentration anomalies: Streamfunction in units of $10^{5} \mathrm{~m}^{2} / \mathrm{s}^{2}$ averaged over December-February: $2^{\text {nd }} \operatorname{EOF}, \operatorname{EOF} 2 \Psi(C-C a)$, representing $22 \%$ of the streamfunctions' variability, explaining $39.4 \%$ of the record. Shown is the spatial extent of the pattern as determined by the regression model. Arrows indicate the local wind direction and wind speed anomaly (proportional to the length of the arrow) and are displayed to facilitate the interpretation of the pattern

streamfunction. It shows a cyclonic flow south of Greenland and a blocking situation over north-eastern Europe (Fig. 5). Thus, the air masses are transported from the south/south-east to the ice core drill sites. The identified period from December-February and especially the spatial pattern of the flow regime is unexpected. However, extending the season in the regression analysis to the expected season of maximum dust input (i.e. spring) does not change the streamfunction pattern significantly nor does the validation fail. Although the explained variance of the ice core data falls from 39.4 to about $29 \%$ for December-April, the timing is thus not in contradiction with that observed in ice cores.

The two cores defining the NW-Ca record have very low common variability (PC1 explaining only $53 \%$ of the variability of one core, compared to $50 \%$ if the cores were totally independent). This could be expected from their different meteorological and glaciological conditions, i.e. high accumulation regime with wet deposition dominating at NASA-U compared to low accumulation rate with significant contribution from dry deposition at Humboldt. Despite this, we performed our regression analysis, finding a similar but less pronounced circulation pattern (not shown) as for C-Ca. The pattern represents the time from January to June. NW-Ca is not included in the following discussion, as it does not provide any additional information.

Figure 6 shows the regional ice core time series and the corresponding PCs of the streamfunction patterns obtained from the regression model. The best fit is obtained for $\mathrm{C}-\mathrm{Ca}$, for which the explained variance of the cross-validated reconstruction is $39 \%$ compared 

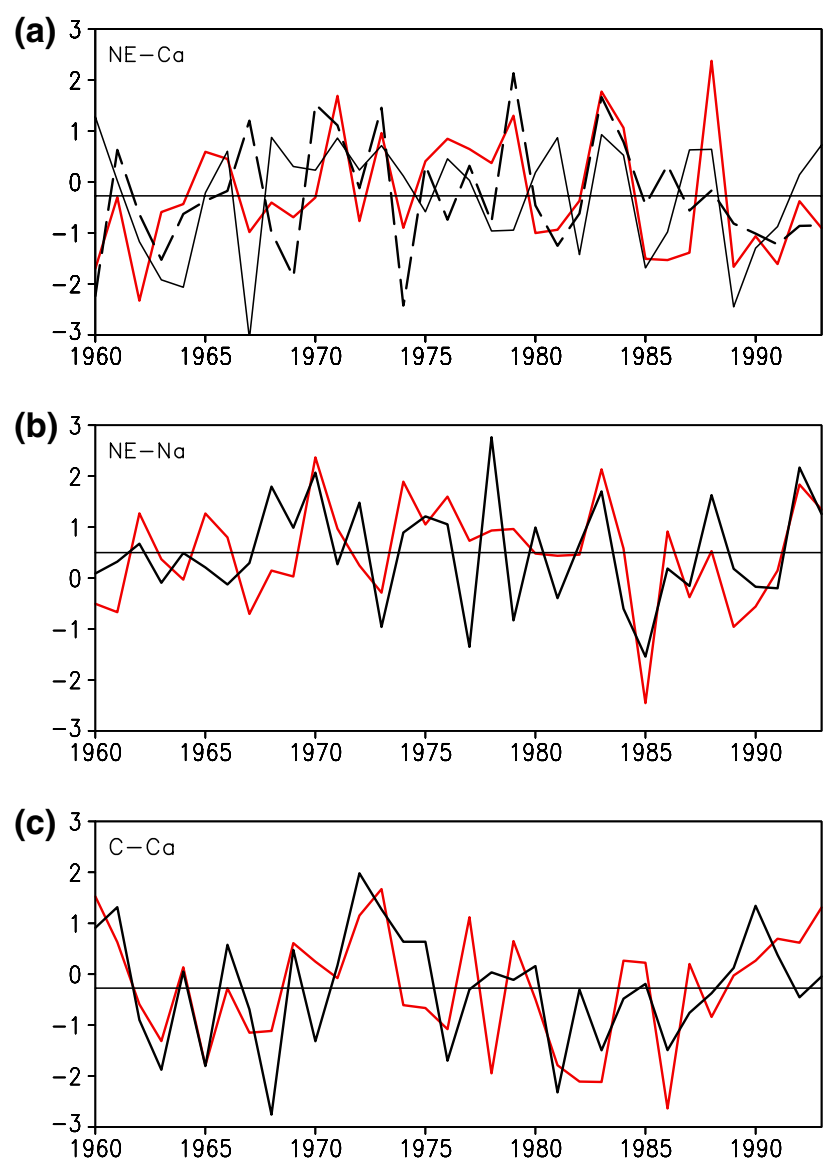

Fig. 6 Ice core PC1 (red) and streamfunction PCs (black) obtained from the regression models. a NE-Ca (solid black $\mathrm{PC} 1 \psi$, dashed black $\mathrm{PC} 2 \psi)$, b NE-Na, c C-Ca

with $32 \%$ for NE-Ca and $30 \%$ for NE-Na. Note that the validation generally yields smaller amounts of explained variance than the calibration without validation (i.e. the PC's), because of the reduced information during the validation procedure.

\section{Discussion}

The circulation patterns explaining the largest fraction of the variances of the four regional time series were found in winter (NE-Na), winter/spring (C-Ca) and spring/summer (NE-Ca, NW-Ca,), i.e. the seasons when $\mathrm{Ca}^{2+}$ and $\mathrm{Na}^{+}$concentrations in Greenland ice cores peak (Beer et al. 1991; Fischer and Wagenbach 1996; Fischer 1997; Mayewski et al. 1987; Steffensen 1988). It should be noted that the seasons are not very stringently constrained, first because the months of the annual $\mathrm{Ca}^{2+}$ and $\mathrm{Na}^{+}$concentration peaks will vary from year to year, and that in the ice core records used the timing of peaks is associated with an uncertainty of a few months. However, the fact that the regression model found seasons consistent with observations by using the annual $\mathrm{Ca}^{2+}$ and $\mathrm{Na}^{+}$indicates that a large fraction of the inter-annual variability in the regional time series is indeed not noise but represents a climatic signal.

Previous research indicated that the dominant fraction of mineral dust deposited over Greenland originates almost exclusively from desert areas in Asia (Bory et al. 2002, 2003). The EOF2 ${ }_{\Psi}(\mathrm{NE}-\mathrm{Ca})$ pattern (Fig. 3a) and the implied westerly flow over the northern parts of Greenland linked with higher $\mathrm{Ca}^{2+}$ values, is consistent with the expected transport of dust from these sources to Greenland (e.g. Kahl et al. 1997).

The EOF1 ${ }_{\Psi}(\mathrm{NE}-\mathrm{Ca})$ pattern (Fig. 3b), which explains $14 \%$ of the variance of the NE-Ca record, is similar to the pattern EOF5 ${ }_{\Psi}(\mathrm{NE}-\mathrm{Na})$ (Fig. 4). Both patterns indicate that high concentrations are linked with transport from the south-east/east to the drill sites. At first sight this would suggest a North-Atlantic/ Greenland sea marine source for both $\mathrm{Ca}^{2+}$ and $\mathrm{Na}^{+}$. While sensible for $\mathrm{Na}^{+}$, which is of primarily marine origin, in the case of $\mathrm{Ca}^{2+}$ this is surprising and seemingly inconsistent with an exclusively Asian dust source. A regional dust source contributing any significant amount to the dust deposited over Greenland is also unlikely due to the fact that $\mathrm{Ca}^{2+}$ concentrations in snow do not depend on altitude (Fig. 7a) in the dry snow zone of the GrIS. An altitude dependence would be expected for regional dust sources, as seen in Bory et al. (2003), because much of the dust mass is progressively deposited when transported from low altitude sources onto the ice sheet. Unlike $\mathrm{Ca}^{2+}, \mathrm{Na}^{+}$ concentrations clearly show this dependency, consistent with its source in the neighbouring seas (Fig. 7b).

In this study we used total $\mathrm{Ca}^{2+}$ rather than nonsea-salt $\mathrm{Ca}^{2+}$ (nssCa), thus a fraction of the $\mathrm{Ca}^{2+}$ is of sea salt origin. However, the sea salt fraction of $\mathrm{Ca}^{2+}$ (ssCa) contributes less than $7 \%$ to the total $\mathrm{Ca}^{2+}$ for the cores where $\mathrm{Na}^{+}$was available using the well established sea water ratio of $\mathrm{ssCa}[\mathrm{ppb}] /$ $\mathrm{ssNa}[\mathrm{ppb}]=0.038$ (Sverdrup et al. 1942). More relevant for the present study investigating variabilities rather than absolute values, is the standard deviation of ssCa. The latter is on the order of only $0.1 \mathrm{ppb}$ compared to $4.8-10.1 \mathrm{ppb}$ for total $\mathrm{Ca}^{2+}$. Thus, ssCa can not be responsible for the $14 \%$ variance in NE$\mathrm{Ca}$ explained by $\mathrm{EOF}_{\Psi}(\mathrm{NE}-\mathrm{Ca})$. An additional indication that ssCa does not contribute significantly to the total $\mathrm{Ca}^{2+}$ variability comes from the fact that $\mathrm{EOF} 1_{\Psi}(\mathrm{NE}-\mathrm{Ca})$ and $\mathrm{EOF} 5 \Psi(\mathrm{NE}-\mathrm{Na})$ represent different periods of the year, indicating that $\mathrm{Ca}^{2+}$ and $\mathrm{Na}^{+}$are decoupled, i.e. are not transported together 


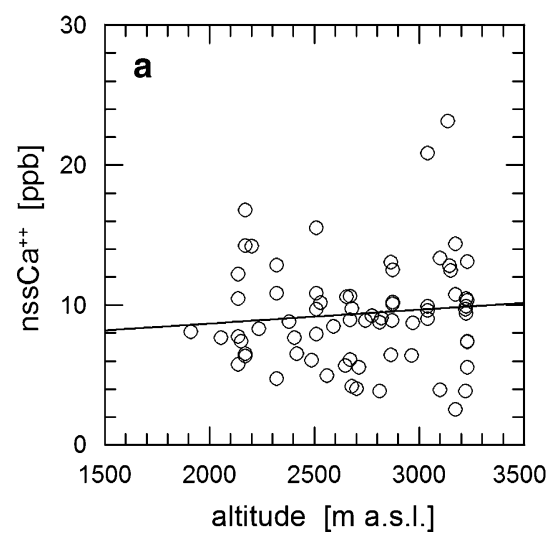

Fig. 7 Altitude dependence of $\mathbf{a}$ nss $\mathrm{Ca}^{2+}$ and $\mathbf{b ~ N a}{ }^{+}$concentrations in north to central Greenland snow pits and shallow ice cores (lines are linear regressions). Data are from the AWI North Greenland traverse 1993-1995 (Fischer 1997), the EGIG

in the same air masses, consistent with the different timing of the $\mathrm{Ca}^{2+}$ and $\mathrm{Na}^{+}$peaks observed in ice cores.

We suggest that the variability in NE-Ca related to $\mathrm{EOF} 1_{\Psi}(\mathrm{NE}-\mathrm{Ca})$ reflects inter-annual variability of wet deposition at the corresponding ice core sites during spring as opposed to variability in the dust source and/ or long-range transport.

Dry deposition of dust dominates the concentrations in the snow during periods of very low accumulation, and particularly in spring when the dust loading is high. However, because of the much higher efficiency of wet versus dry deposition of aerosols to the snow surface, sporadic precipitation events will very efficiently scavenge dust particles from the air. This may thus strongly modulate aerosol deposition during the spring peak season and introduce significant inter-annual variability to the dust concentration in the ice.

However, this variability can have two opposite effects on ice core aerosol records: If the snowfall originated from air masses void of, or depleted in the aerosol in question, it can decrease average concentrations in ice cores by diluting the deposited material when looking at averages longer than the single precipitation event. This will lead to a negative correlation of aerosol concentration in snow with accumulation rate, which is typically seen at very low accumulation sites, where dry deposition is responsible for most of the aerosol mass deposited (e.g. Wolff et al. 2006; Legrand 1987). If the precipitation originates from air masses rich in the aerosol in question, i.e. bringing an above average amount to the surface, this will lead to elevated concentrations in the snow and thus to a positive correlation of the ice core record with accumulation rate. Such a behavior is also supported by the

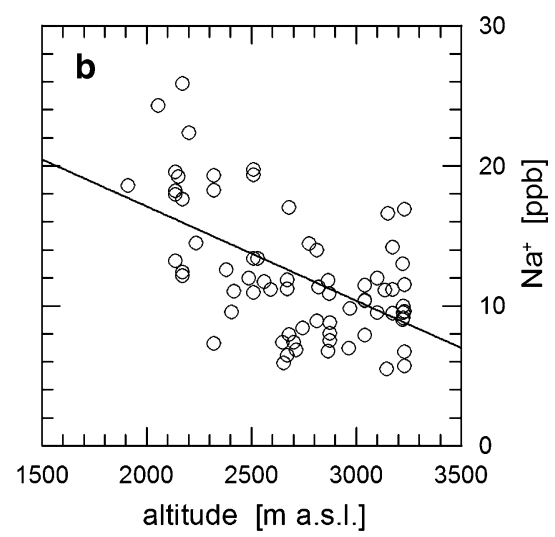

traverses 1990-1992, Site A, and Summit, central Greenland (Laj et al. 1992; Savarino 1996; Whitlow et al. 1992; Fischer et al. 1996). Shown are temporal averages ranging from 5 up to 500 years

high scavenging ratios of mineral dust aerosol by polar snow (Davidson et al. 1996).

A positive wet deposition anomaly leading to increased NE-Ca implies more efficient $\mathrm{Ca}^{2+}$ deposition onto the ice sheet in single precipitation events compared to spring seasons with no or less snowfall. This also means that there must be some (Asian) dust present in the air masses over the GrIS. This is not unreasonable given that the dust deflated from the Takla Makan Desert, West China, which is thought to be the source supplying most if not all of the mineral particles during the dusty spring season to Greenland, is usually entrained to elevations $>5,000 \mathrm{~m}$ before being transported by the westerly jet stream over the remote North Pacific Ocean (Sun et al. 2001; Bory et al. 2002, 2003). It can thus be assumed that the comparatively small dust particles arriving at high altitudes over the GrIS region will lead to relatively homogeneous background dust concentrations in the lower atmospheric layers over the Arctic in spring. The above-mentioned observed absence of an altitude dependence of $\mathrm{Ca}^{2+}$ concentrations over the GrIS further supports this scenario.

The accumulation rates of $\sim 10 \mathrm{~cm}$ weq/a in NEGreenland (Bales et al. 2001; Dethloff et al. 2002) are typical for a regime where both, dry deposition and wet deposition are important. Accordingly, our results suggest that the inter-annual variability of the $\mathrm{Ca}$ record associated with $\mathrm{EOF} 2 \Psi(\mathrm{NE}-\mathrm{Ca})$ in this area is dominated by dry deposition and the inter-annual variability associated with $\mathrm{EOF} 1_{\Psi}(\mathrm{NE}-\mathrm{Ca})$ by wet deposition.

The hypothesis that the $\mathrm{EOF} 1_{\Psi}(\mathrm{NE}-\mathrm{Ca})$ pattern is related to wet deposition is confirmed by the significant correlation (95\% significance level, $r=0.34$ ) between 
March-August ERA-40 snowfall in the NE-Ca region and the corresponding PC of $\mathrm{EOF} 1_{\Psi}(\mathrm{NE}-\mathrm{Ca})$. On the other hand, no significant correlation of ERA-40 snowfall and the PC of EOF2 ${ }_{\Psi}(\mathrm{NE}-\mathrm{Ca})$ was found, in line with dry deposition. Given that the latter pattern explains a larger fraction $(30 \%)$ of the variability of NE-Ca than $\mathrm{EOF} 1_{\Psi}(\mathrm{NE}-\mathrm{Ca})(14 \%)$, it is not surprising that NE-Ca itself is not correlated with spring snowfall either. The correlations do not change significantly using snowfall minus snow evaporation instead, which corresponds more closely to accumulation rather than precipitation, and when using annual snowfall averages. Although dry deposition is important in $\mathrm{NE}$ Greenland, the amount of wet deposition in spring apparently is enough to counteract the negative correlation between annual snow accumulation (the latter being dominated by summer through winter precipitation when atmospheric dust is low) and annual $\mathrm{Ca}^{2+}$ concentrations typical for very low accumulation sites (Legrand 1987; Alley et al. 1995; Kreutz et al. 2000; Wolff et al. 2006).

The easterly/south-easterly flow towards the NE of the GrIS related to EOF5 ${ }_{\Psi}(\mathrm{NE}-\mathrm{Na})$ point to a sea salt source in the Greenland sea (Fig. 4). This is consistent with previous results showing a significant correlation of snow accumulation in the NE of the GrIS and cyclonic activity over the Greenland sea (Hutterli et al. 2005; Crüger et al. 2004), given that sea salt aerosols and water vapor tend to be closely coupled by sharing a common source region and transport (Fischer and Mieding 2005). This coupling also implies that most of the sea salt aerosols will subsequently be wet deposited, leaving only a small fraction of the original aerosol mass available for potential dry deposition. The conditions are exactly opposite in the case of dust storms, which are intrinsically linked with dry conditions, a prerequisite for entraining dust. Most dust particles produced after a dust storm are dry deposited within a relatively short period of time. The smallest particles may, however, remain in the atmosphere for a few weeks and can be transported over large distances (Ginoux et al. 2001).

In contrast to NE Greenland, the C-Ca region, with accumulation rates exceeding $20 \mathrm{~cm}$ weq/a, is dominated by wet deposition. Following the above arguments it would seem reasonable that the regression model only found the one pattern $\mathrm{EOF} 2 \Psi(\mathrm{C}-\mathrm{Ca})$, suggesting a relationship to moist marine air masses from the west as it is the case for $\mathrm{EOF} 1 \Psi(\mathrm{NE}-\mathrm{Ca})$ and EOF5 ${ }_{\Psi}(\mathrm{NE}-\mathrm{Na})$. However, given that the cores are close to or west of the ice divide, air masses arriving at the $\mathrm{C}-\mathrm{Ca}$ region from the east will have lost a significant part of their original moisture content on their way. Indeed, in contrast to $\mathrm{EOF} 1_{\Psi}(\mathrm{NE}-\mathrm{Ca})$ the $\mathrm{PC}$ of $\mathrm{EOF} 2 \Psi(\mathrm{C}-\mathrm{Ca})$ is negatively correlated with the corresponding ERA-40 snowfall $(r=-0.30$; $92 \%$ confidence level). A composite analysis indicates that for years with values $>1 \sigma$ above the mean of $\mathrm{PC}$ of EOF2 $4(\mathrm{C}-\mathrm{Ca})$, seasonal average ERA-40 snowfall is $-33 \%$ lower than for the years with $\mathrm{PC}$ values $<1 \sigma$ below the mean. This suggests that in this high accumulation regime snowfall leads to a dilution rather than an enhancement of $\mathrm{Ca}^{2+}$ concentrations in snow.

However, there is no correlation $(r=0.008)$ between C-Ca and the ERA-40 snowfall in the corresponding region either for seasonal or for annual snow accumulation records. A negative correlation would be expected, if individual snowfall events were to dilute the annual $\mathrm{Ca}^{2+}$ concentrations. The lack of such a relationship supports previous results suggesting that the concentrations of impurities in snow at these high accumulation sites are independent of the accumulation rate (e.g. Alley et al. 1995; Kreutz et al. 2000; Burkhart et al. 2004).

If it is neither accumulation rate nor transport of dust, then what process causes the close link between the inter-annual variability in $\mathrm{Ca}^{2+}$ concentrations and the $\mathrm{EOF}_{2}(\mathrm{C}-\mathrm{Ca})$ pattern (Fig. 5), i.e. the positive correlation of $\mathrm{C}-\mathrm{Ca}$ with $\mathrm{PC}$ of $\mathrm{EOF} 2 \Psi(\mathrm{C}-\mathrm{Ca})$ ? One possible explanation is that the intensity of a precipitation event, i.e. the total amount of snowfall, modulates the average $\mathrm{Ca}^{2+}$ concentrations of the snow deposited during the event: This would be the case when a relatively low intensity precipitation event scavenges and deposits essentially all dust present in and below the cloud. This is expected from the high scavenging ratios of mineral dust aerosol by polar snow (Davidson et al. 1996) and is in particular true for fog deposition events, which can efficiently deposit soluble species leading to high concentrations (Bergin et al. 1995, 1996). Higher intensity precipitation events will then result in lower than average aerosol concentrations in snow. It is thus plausible that precipitation events associated with a positive $\mathrm{EOF}{ }_{\Psi}(\mathrm{C}-\mathrm{Ca})$ pattern (i.e. dryer air masses from the east) are generally of lower intensity compared to events during a negative $\mathrm{EOF} 2 \Psi(\mathrm{C}-\mathrm{Ca})$ pattern with moist air masses from the west. This would then explain both the positive correlation of $\mathrm{C}-\mathrm{Ca}$ with the $\mathrm{PC}$ of $\mathrm{EOF} 2 \Psi(\mathrm{C}-\mathrm{Ca})$ and the lack of a correlation with ERA-40 snowfall. In addition, the lower accumulation during positive EO$\mathrm{F} 2 \Psi(\mathrm{C}-\mathrm{Ca})$ patterns will lead to a higher relative contribution (i.e. less dilution) of dry deposition, and higher sublimation rates, both further increasing surface snow $\mathrm{Ca}^{2+}$ concentrations. 
We thus suggest that the large fraction (39\%) of the inter-annual $\mathrm{Ca}^{2+}$ variability in Central Greenland is caused by the variability in intensity of snowfall events in spring, which in turn may be linked to the frequency of fog deposition events.

\section{Summary and conclusions}

Our results suggest that a large fraction of the interannual variability measured in ice core aerosol records result from the complex modulation of aerosol concentrations in snow by dry and wet deposition, the latter being driven by distinct regional circulation patterns. Dry deposition is a continuous and relatively simple process leading to an aerosol flux onto the ice sheet, which essentially scales with local atmospheric concentrations (assuming a relatively constant deposition velocity).

Contrary to previous assumptions, our results suggest that depending on the timing and intensity of the precipitation, wet deposition can either lead to no change or a decrease in annual aerosol concentrations in ice cores or to an increase. Snowfall during the seasons of low or no $\mathrm{Ca}^{2+}$ and $\mathrm{Na}^{+}$aerosol loading (i.e. summer through winter) will generally dilute annual average concentrations in snow leading to negative correlations of ice core aerosol concentrations and accumulation rate. At a given atmospheric aerosol loading, the average concentration of a precipitation event will inversely scale with its intensity (amount of precipitation deposited during a specific event). Thus, low intensity snowfall and particularly also fog deposition events during the high aerosol spring season tend to increase aerosol concentrations in snow, whereas high intensity events potentially dilute them.

Because average accumulation rates are determined by both, the frequency and the intensity of precipitation events, simple relationships between accumulation rate and ice core aerosol concentration can in general not be expected [except in the absence of wet deposition during the high aerosol season, which is e.g. the case for extremely low accumulation rates found on the East Antarctic Plateau (e.g. Wolff et al. 2006)].

One of the main outcomes of our study is that mineral dust and sea salt aerosol deposition is mainly influenced by regional circulation and precipitation patterns over Greenland, while our method did not identify large-scale (hemispheric) circulation patterns to control aerosol transport onto Greenland in a statistical significant way. Only in the case of mineral dust in Northeastern Greenland the inter-annual variability of the regional $\mathrm{Ca}^{2+}$ record is associated with transport related to larger scale westerly circulation (Fig. 3a). $\mathrm{Ca}^{2+}$ in Greenland ice cores predominately derives from mineral dust and the strongest of the associated circulation patterns is in agreement with findings from several sites on the interior GrIS showing dust sources in central Asia (Bory et al. 2002, 2003). Easterly flow towards the ice core sites in northeastern Greenland indicated by both the second strongest circulation pattern for $\mathrm{Ca}^{2+}$ (Fig. 3b) and the circulation pattern associated with $\mathrm{Na}^{+}$variability (Fig. 4) suggests common mechanisms of deposition of these species onto the GrIS. However, they are not deposited synchronously, and are thus not scavenged from the same air masses. Correlation analyses with ERA-40 snowfall fields suggest that dust deposited in conjunction with westerly flow is most likely dry deposited. It may reflect inter-annual variability in the long-range transport and possibly dust source variability in central Asia. In contrast, the easterly circulation pattern is likely connected to mainly wet deposited dust. The intensities of wet deposition events in this area are generally low enough to lead to a positive correlation of dust concentration with the seasonal snow accumulation associated with the $\mathrm{EOF} 1_{\Psi}(\mathrm{NE}-\mathrm{Ca})$ stream function pattern. The same is also true for $\mathrm{EOF}_{\Psi}(\mathrm{NE}-\mathrm{Na})$.

In northeastern Greenland, inter-annual $\mathrm{Na}^{+}$variability is associated with an easterly/southeasterly flow suggesting a $\mathrm{Na}^{+}$source in the Greenland sea followed by a predominantly wet deposition of the sea salt aerosols (Fig. 4). It has not been possible to verify a circulation pattern for $\mathrm{Na}^{+}$in central Greenland, as we only have one $\mathrm{Na}^{+}$record with sufficient resolution.

For the central part of the GrIS, where wet deposition dominates, only one single significant circulation pattern associated with $\mathrm{Ca}^{2+}$ variability could be found. This pattern suggests a south-easterly transport associated with elevated $\mathrm{Ca}^{2+}$ values and low accumulation rates. Based on the latter and in conjunction with the missing correlation of accumulation rate and $\mathrm{C}-\mathrm{Ca}$, we suggest that the precipitation intensity (amount of precipitation in a single event) is causing the observed inter-annual $\mathrm{Ca}^{2+}$ variability in this region as opposed to average precipitation rates (which would lead to a negative correlation).

From our results we therefore conclude that a high fraction $(39 \%)$ of the interannual C-Ca variability is determined by the variability of precipitation intensity associated with the EOF $2 \Psi(\mathrm{C}-\mathrm{Ca})$ streamfunction pattern and might potentially be dominated by the frequency of fog events. 
Although the sources of dust found on the interior GrIS are known to be situated in Central Asia, the study presented here shows that inter-annual variability in ice core dust concentration is strongly modulated by regional atmospheric circulation patterns and precipitation events. Numerical deposition models describing the complex interplay of atmospheric circulation and the various deposition processes (including fog and snow sublimation) and corresponding in situ measurements are needed to improve our understanding of the inter-annual variability of ice-core aerosol records.

It should be mentioned that the variability in dust and sea salt sources are modulated by near surface variables such as wind speed, relative humidity and sea ice cover, which were not investigated. It is therefore conceivable that part of the unexplained fraction of the inter-annual variability in our ice core records stems from the variability in the source strengths.

Further, it is interesting to note that the variance in the regional records explained by the streamfunction patterns $\mathrm{EOF}_{\Psi}(\mathrm{NE}-\mathrm{Ca}), \mathrm{EOF}_{\Psi}(\mathrm{NE}-\mathrm{Na})$ and $\mathrm{EO}-$ $\mathrm{F} 2 \Psi(\mathrm{C}-\mathrm{Ca})$ is of the same order or higher than the maximum explained variance of the NAO in ice core accumulation records (32\%, NASA-U, Appenzeller et al. 1998). Thus a reconstruction of both, deposition regimes and potentially fog deposition frequency, and the inter-annual variability of the regional circulation patterns, could be attempted.

In similar future studies, the aerosol spring peak area rather than annual averages could be used to improve fractions of explained variances by reducing the noise introduced by the inter-annual variability of accumulation during the seasons of low atmospheric aerosol loading. For this, however, more seasonally resolved ice core records are needed.

\footnotetext{
Acknowledgments This work was supported by the Project entitled "Patterns of Climate Variability in the North Atlantic (PACLIVA)" funded the by European Commission under the Fifth Framework Programme Contract Nr. EVR1-2002-000413, and the National Centre for Competence in Research (NCCR) on Climate funded by the Swiss National Science Foundation. KKA thanks the Carlsberg foundation for funding. Collection and analyses of the D2, D3, NASA-U, DAS1, and UAK1 cores was supported by grants from NASA's Cryospheric Sciences Program and the Summit99 core by grants from NSF's Arctic Natural Sciences program. R.C.B. and J.F.B. were supported by NASA grants NAG5-6779, NAG5-10264 and NASA Earth System Science Fellowship awarded to J.F.B. ERA-40 re-analysis data were provided by European Centre for Medium-Range Weather Forecasts (ECMWF, http://www.data.ecmwf.int/data/ index.html). We thank D. Wagenbach and R. Röthlisberger for helpful discussions and M. Frey and D. Belle-Oudry for help with ice core analyses.
}

\section{References}

Alley RB, Finkel RC, Nishiizumi K, Anandarkishnan S, Shuman CA, Mershon G, Zielinski GA, Mayewski PA (1995) Changes in continental and sea-salt atmospheric loadings in central Greenland during the most recent deglaciation: model-based estimates. J Glaciol 41(139):503-514

Anklin M, Bales RC, Mosley-Thompson E, Steffen K (1998) Annual accumulation at two sites in Northwest Greenland during recent centuries. J Geophys Res 103(D22):2877528783

Appenzeller C, Stocker TF, Anklin M (1998) North Atlantic Oscillation dynamics recorded in Greenland ice cores. Science 282:446-449

Bales RC, McConnell JR, Mosley-Thompson E, Lamorey G (2001) Accumulation map for the Greenland ice sheet: 1971-1990. Geophys Res Lett 28:2967-2970

Barnston AG, Livezey RE (1987) Classification, seasonality and persistence of low-frequency atmospheric circulation patterns. Mon Wea Rev 115:1083-1126

Beer J, Finkel RC, Bonani G, Gäggeler H, Glach U, Jacob P, Klockow D, Langway CCJ, Neftel A, Oeschger $\mathrm{H}$, Schotterer U, Schwander J, Siegenthaler U, Suter M, Wagenbach D, Wölfli W (1991) Seasonal variations in the concentrations of ${ }^{10} \mathrm{Be}, \mathrm{Cl}^{-}, \mathrm{NO}_{3}^{-}, \mathrm{SO}_{4}^{2-}, \mathrm{H}_{2} \mathrm{O}_{2},{ }^{210} \mathrm{~Pb},{ }^{3} \mathrm{H}$, mineral dust, and $\delta^{18} \mathrm{O}$ in Greenland snow. Atmos Environ 25(19):899-904

Bergin MH, Pandis SN, Davidson CI, Jaffrezo J-L, Dibb JE, Russell AG, Kuhns HD (1996) Modeling of the processing and removal of trace gas and aerosol species by Arctic radiation fogs and comparison with measurements. J Geophys Res 101(D9):14465-14478

Bergin MH, Jaffrezo J-L, Davidson CI, Dibb JE, Pandis SN, Risto Hillamo, Maenhaut W, Kuhns HD, Mäkelä T (1995) The contribution of snow, fog, and dry deposition to the summer flux of anions and cations at Summit, Greenland. J Geophys Res 100(D8):16275-16288

Bory AJ-M, Biscaye PE, Svensson A, Grousset FE (2002) Seasonal variability in the origin of recent atmospheric mineral dust at NorthGRIP, Greenland. Earth Planet Sci Lett 196(3-4):123-134

Bory AJ-M, Biscaye PE, Piotrowski AM, Steffensen JP (2003) Regional variability of ice core dust composition and provenance in Greenland. Geochem Geophy Geosys 4(12). DOI 10.1029/2003GC000627

Burkhart JF, Bales RC, McConnell JR, Hutterli MA (2006) Influence of the North Atlantic Oscillation on anthropogenic transport recorded in Northwest Greenland ice cores. J Geophys Res (in press)

Burkhart JF, Hutterli MA, Bales RC, McConnell JR (2004) Seasonal accumulation timing and preservation of nitrate in firn at Summit, Greenland. J Geophys Res 109(D19302). DOI 10.1029/2004JD004658

Casty C, Raible CC, Stocker TF, Wanner H, Luterbacher J (2006) European climate pattern variability since 1766. Clim Dyn (in press)

Cook ER, D'Arrigo RD, Mann ME (2002) A well-verified, multiproxy reconstruction of the winter North Atlantic Oscillation index since AD 1400. J Clim 15(13):17541764

Crüger T, von Storch H (2002) Creation of "artificial ice core" accumulation from large-scale GCM data: description of the downscaling method and application to one north Greenland ice core. Clim Res 20:141-151 
Crüger T, Fischer H, von Storch H (2004) What do accumulation records of single ice cores in Greenland represent? J Geophys Res 109(D21110). DOI 10.1029/2004JD005014

Davidson CI, Bergin MH, Kuhns HD (1996) The deposition of particles and gases to ice sheets. In: Wolff EW, Bales RC (eds) Chemical exchange between the atmosphere and polar snow. NATO ASI Series, I43 Springer, Berlin Heidelberg New York, 275-306

Dethloff K, Schwager M, Christensen JH, Kiilsholm S, Rinke A, Dorn W, Jung-Rothenhäusler F, Fischer H, Kipstuhl S, Miller H (2002) Recent Greenland accumulation estimated from regional climate model simulations and ice core results. J Clim 15:2821-2832

Fischer H (1997) Räumliche Variabilität in Eiskernzeitreihen Nordostgrönlands - Rekonstruktion klimatischer und luftchemischer Langzeittrends seit 1500 AD. PhD thesis, Institut für Umweltphysik, Universität Heidelberg

Fischer H, Mieding B (2005) A 1,000-year ice core record of annual to multidecadal variations in atmospheric circulation over the North Atlantic. Clim Dyn 25:65-74. DOI 10.1007/ s00382_00005_00011_x

Fischer H, Wagenbach D (1996) Large-scale spatial trends in recent firn chemistry along an east-west transect through central Greenland. Atmos Environ 30(19):3227-3238

Ginoux P, Chin M, Tegen I, Prospero JM, Holben B, Dubovik O, Lin S-J (2001) Sources and distributions of dust aerosols simulated with the GOCART model. J Geophys Res 106(D17):20255-20274. DOI 10.1029/2000JD000053

Gong D, Wang S (1999) Definition of Antarctic Oscillation index. Geophys Res Lett 26(4):459-462

Hurrell JW, Kushnir Y, Visbeck M (2001) The North Atlantic Oscillation. Science 291:603-605

Hutterli MA, Raible CC, Stocker TF (2005) Reconstructing climate variability from Greenland ice sheet accumulation: an ERA-40 study. Geophys Res Lett 32(L23712). DOI 23710.21029/22005GL024745

Kahl JDW, Martinez DA, Kuhns H, Davidson CI, Jaffrezo J-L, Harris JM (1997) Air mass trajectories to Summit, Greenland: a 44 year climatology and some episodic events. J Geophys Res 102(C12):26861-26875

Kalnay E, et al. (1996) The NCEP/NCAR 40 year reanalysis project. Bull Am Meteorol Soc 77:437-471

Kreutz KJ, Mayewski PA, Meeker LD, Twickler MS, Whitlow SI (2000) The effect of spatial and temporal accumulation rate variability in West Antarctica on soluble ion deposition. Geophys Res Lett 27(16):2517-2520

Laj P, Palais JM, Sigurdsson H (1992) Changing sources of impurities to the Greenland ice sheet over the last 250 years. Atmos Environ 26(14):2627-2640

Legrand M (1987) Chemistry of Antarctic snow and ice. J Phys 48(C1):77-86

Legrand M, Mayewski P (1997) Glaciochemistry of polar ice cores: a review. Rev Geophys 35:219-243

Luterbacher J, Xoplaki E, Dietrich D, Jones PD, Davis TD, Portis D, Gonzalez-Ruoco JF, von Storch H, Gyalistras D, Casty C, Wanner H (2002) Extending the North Atlantic Oscillation reconstruction back to 1500 . Atmosph Sci Lett (2):114-124. DOI 10.1006/asle.2001.0044

Mayewski PA, Spencer MJ, Lyons WB, Twickler MS (1987) Seasonal and spatial trends in south Greenland snow chemistry Atmos Environ 21(4):863-869

McConnell JR, Lamorey GW, Lambert SW, Taylor KC (2002a) Continuous ice-core chemical analyses using inductively coupled plasma mass spectrometry. Environ Sci Techn 36(1):7-11
McConnell JR, Lamorey GW, Hutterli MA (2002b) A 250-year high-resolution record of $\mathrm{Pb}$ flux and crustal enrichment in central Greenland. Geophys Res Lett 29(23):2130. DOI 10.1029/2002GL016016

Michaelsen J (1987) Cross-validation in statistical climate forecast models. J Clim Appl Meteorol 26:1589-1600

Mieding B (2005) Rekonstruktion tausendjähriger aerosolchemischer Eiskernzeitreihen aus Nordostgrönland: quantifizierung zeitlicher Veränderungen in Atmosphärenzirkulation. Emission and Deposition, PhD thesis, Universität Bremen, 1-119 pp

Mosley-Thompson E, Readinger CR, Craigmile P, Thompson LG, Calder CA (2005) Regional sensitivity of Greenland precipitation to NAO variability. Geophys Res Lett 32(L24707). DOI 24710.21029/22005GL024776

North Greenland Ice-Core Project (NorthGRIP) Members (2004) High-resolution climate record of the northern hemisphere reaching into the last interglacial period. Nature 431(7005):147-151

Philander SG (1990) El Niño, La Niña, and the Southern Oscillation. Academic, San Diego

Raible CC, Casty C, Luterbacher J, Pauling A, Esper J, Frank DC, Büntgens U, Roesch AC, Wild M, Tschuck P, Vidale P-L, Schär C, Wanner H (2006) Climate variability-observations, reconstructions and model simulations model simulations for the Atlantic-European and Alpine Region from 1500-2100 AD. Clim Change. DOI 10.1007/s10584-006-9061-2

Röthlisberger R, Bigler M, Hutterli MA, Sommer S, Junghans HG, Wagenbach D (2000) Technique for continuous highresolution analysis of trace substances in firn and ice cores. Environ Sci Techn 34:338-342

Savarino J (1996) Chimie de la carotte EUROCORE (Groenland central): variabilite des emissions biologiques au cours du dernier millenaire. PhD thesis, Universite Joseph Fourier, LGGE, CNRS Grenoble, France, 336p

Simmons AJ, Gibson JK (2000) The ERA-40 project plan. Eur Cent for Med-Range Weather Forecasting, Reading, UK, 63pp

Sommer S (1996) Hochauflösende Spurenstoffuntersuchungen an eisbohrkernen aus Nord-Grönland, MS thesis, University of Bern, Switzerland

Steffensen JP (1988) Analysis of the seasonal variation in dust, $\mathrm{Cl}^{-}, \mathrm{NO}_{3}^{-}$, and $\mathrm{SO}_{4}^{-}$in two central Greenland firn cores. Ann Glaciol 10:171-177

Sun JM, Zhang MY, Liu TS (2001) Spatial and temporal characteristics of dust storms in China and its surrounding regions 1960-1999: relations to source area and climate. J Geophys Res 106:10325-10333

Sverdrup HU, Johnson MW, Flemming RH (1942) The Oceans. Prentice Hall Inc. New York, p 1087

Thompson DWJ, Wallace G (2000) Annular modes in the extratropical circulation. Part I: Month-to-month variability. J Clim 13:1000-1016

Vinther BM, Clausen HB, Johnsen SJ, Rasmussen SO, Andersen KK, Buchardt SL, Seierstad IK, Siggaard-Andersen M-L, Steffensen JP, Svensson AM, Olsen J, Heinemeier J (2006) A synchronized dating of three Greenland ice cores throughout the Holocene. J Geophys Res. DOI 10.1029/ 2005JD006921 (in press)

Vinther BM, Johnsen SJ, Andersen KK, Clausen HB, Hansen AW (2003) NAO signal recorded in the stable isotopes of Greenland ice cores. Geophys Res Lett 30(7):1387. DOI 1310.1029/2002GL016193

Wallace JM, Thompson DWJ (2002) Annular modes and climate prediction. Phys Today 55(2):28-33 
Whitlow S, Mayewski PA, Dibb JE (1992) A comparison of major chemical species seasonal concentration and accumulation at the South Pole and Summit Greenland. Atmos Environ 26(11):2045-2054

Wolff EW, Fischer H, Fundel F, Ruth U, Twarloh B, Littot GC, Mulvaney R, Röthlisberger R, De Angelis M, Boutron CF, Hansson M, Jonsell U, Hutterli MA, Lambert F, Kaufmann
P, Stauffer B, Stocker T, Steffensen JP, Bigler M, SiggaardAndersen M-L, Udisti R, Becagli S, Castellano E, Severi M, Wagenbach D, Barbante C, Gabrielli P, Gaspari V (2006) Southern ocean sea-ice extent, productivity and iron flux over the past eight glacial cycles. Nature 440: 491-496. DOI 10.1038/nature04614 